\title{
Analisis pendapatan pedagang pulsa dan paket data di Kabupaten Tanjung Jabung Barat (Studi Kasus Kecamatan Tungkal Ilir)
}

\author{
Rino Afrialdo*; Zulfanetti; Etik Umiyati \\ Prodi Ekonomi Pembangunan, Fak.Ekonomi dan Bisnis Universitas Jambi \\ *E-mail korespodensi: rinoafrialdd12@gmail.com
}

\begin{abstract}
This research aims to find out and analyze the socio-economic characteristics of pulse kiosks and data packages and to find out and analyze the effect of capital. Product prices sold several credits, and sales volume on pulse and data package traders in Tungkal Ilir District, Tanjung Jabung Barat Regency. The data used in this study is primary data. The analytical tool used is multiple linear regression. The results showed that the variables of capital, the price of products sold, the number of credit balances, and the volume of sales of data packages had a significant effect on the income variable of pulse traders and data packages. In contrast, partially, the variables of working capital and sales volume of data packages had a considerable effect. In comparison, the price of products sold and the number of credit balances do not significantly affect the income variable of pulse traders and package data in Tungkal Ilir District, Tanjung Jabung Barat Regency.
\end{abstract}

Keywords: Traders, Capital, Volume, Balance

\begin{abstract}
Abstrak
Adapun yang menjadi tujuan dari penelitian ini adalah mengetahui dan menganalisis karakteristik sosial ekonomi kios pulsa dan paket data dan mengetahui dan menganalisis pengaruh modal, harga produk yang dijual, jumlah kredit dan volume penjualan terhadap pendapatan pedagang pulsa dan paket data di Kecamatan Tungkal Ilir Kabupaten Tanjung Jabung Barat. Data yang digunakan dalam penelitian ini merupakan data primer. Alat analisis yang digunakan adalah regresi linier berganda. Hasil penelitian menunjukkan bahwa variabel modal, harga produk yang dijual, jumlah saldo pulsa dan volume penjualan paket data berpengaruh signifikan secara bersama-sama terhadap variabel pendapatan pedagang pulsa dan paket data sedangkan secara parsial, variabel modal usaha dan volume penjualan paket data memiliki pengaruh yang signifikan sedangkan harga produk yang dijual dan jumlah saldo pulsa tidak memiliki pengaruh yang signifikan terhadap variabel pendapatan pedagang pulsa dan paket data di Kecamatan Tungkal Ilir Kabupaten Tanjung Jabung Barat.
\end{abstract}

Kata kunci: Pedagang, Modal, Volume, Saldo

\section{PENDAHULUAN}

Salah satu produk komunikasi yang menjadi peran vital dalam memenuhi kebutuhan konsumen di bidang komunikasi wireless adalah ponsel. Pengguna ponsel sendiri di Kecamatan Tungkal Ilir sangat beragam, dari kalangan menengah keatas sampai kalangan bawah. Itu semua tidak terlepas dari fitur-fitur yang dimiliki dan harga ponsel yang bermacam-macam. Fitur ponsel yang paling banyak dicari adalah kamera, musik dan, radio walaupun ada pula fitur-fitur2 lainnya yang menjadi daya tarik pembeli, diantaranya : Bluetooth, infrared, 3G, HSDPA, email, dan lain-lain. 
Data Statista 2019 menunjukkan pengguna internet di Indonesia pada 2018 sebanyak 95,2 juta, tumbuh 13,3\% dari 2017 yang sebanyak 84 juta pengguna. Pada tahun selanjutnya pengguna internet di Indonesia akan semakin meningkat dengan ratarata pertumbuhan sebesar 10,2\% pada periode 2018-2023. Pada 2019 jumlah pengguna internet di Indonesia diproyeksikan tumbuh 12,6\% dibandingkan 2018, yaitu menjadi 107,2 juta pengguna (databoks.katadata.co.id). berdasarkan hal tersebut dapat dikatakan bahwa jumlah pengguna internet di Indonesai semakin tahun semakin meningkat. Hal ini berarti pembelian paket data yang digunakan untuk berinternet di dunia maya juga akan semakin meningkat.

Di Kecamatan Tungkal Ilir sendiri kios pulsa yang menjual isi ulang fisik atau isi ulang elektronik sangat banyak, mulai dari kios yang besar sampai yg hanya berukuran kecil. Semua itu tidak lepas dari jumlah pemakai ponsel di Indonesia yang mencapai lebih dari 75 juta pemakai ponsel dari kalangan menengah ke atas sampai kalangan bawah (Perdana, 2009). Tentunya hal ini berkaitan erat dengan kebutuhan pulsa yang sangat banyak. Dengan banyaknya permintaan pulsa maka kios pulsa yang ada juga sangat banyak seiring dengan permintaan isi ulang pulsa. Hal ini dikarenakan begitu mudahnya membuka kios pulsa, hanya dengan modal awal 125 ribu kita sudah bisa membuka kios pulsa di rumah atau di pinggir jalan.

Hidayaji (2010) melakukan penelitian dengan judul "Analisis Faktor- Faktor yang mempengaruhi Tingkat Pendapatan Usaha Counter Pulsa di Kecamatan Gamping Sleman". Penelitian ini dilakukan untuk menganalisis Faktor-faktor Yang Mempengaruhi Pendapatan Usaha Counter Pulsa di Kecamatan Gamping Sleman, dengan menggunakan analisa regresi berganda. Penelitian ini melibatkan empat variabel yaitu modal kerja, jam kerja, tenaga kerja, dan lama usaha. Sebanyak 51 usaha counter pulsa diambil sebagai sampel berdasarkan metode kluster sampling dan (purposive sampling). Hasil pengujian regresi secara simultan menunjukkan bahwa variabel modal usaha, jam kerja, tenaga kerja dan umur usaha berpengaruh positif terhadap tingkat pendapatan usaha counter pulsa. Hasil pengujian secara parsial menunjukkan variabel modal usaha, jam kerja, umur usaha berpengaruh positif dan signifikan terhadap tingkat pendapatan usaha counter pulsa. Hasil pengujian secara parsial menunjukkan variabel tenaga kerja tidak berpengaruh terhadap tingkat pendapatan usaha counter pulsa.

Ma'rufaa dalam penelitiannya yang berjudul "Pengaruh Modal Usaha, tenaga kerja, jam kerja, dan lama usaha terhadap pendapatan usaha konter pulsa di Kecamatan Gresik (Studi pada Konter pulsa yang terdaftar pada PT. Multimedia Media Selular Cabang Gresik)" dengan menggunakan analisa regresi linier berganda. Hasil penelitian menjelaskan bahwa Modal Usaha, tenaga kerja, jam kerja, dan lama usaha berpengaruh signifikan terhadap pendapatan usaha konter pulsa di Kecamatan Gresik.

Adapun yang menjadi tujuan dari penelitian ini adalah mengetahui dan menganalisis karakteristik sosial ekonomi kios pulsa dan paket data di Kecamatan Tungkal Ilir Kabupaten Tanjung Jabung Barat dan mengetahui dan menganalisis pengaruh modal, harga produk yang dijual, jumlah kredit dan volume penjualan terhadap pendapatan Pedagang Pulsa dan Paket Data di Kecamatan Tungkal Ilir Kabupaten Tanjung Jabung Barat.

\section{METODE}

Data yang digunakan dalam penelitian ini adalah data primer. Data primer adalah data yang dikumpulkan dari suatu objek atau dokumen original material mentah dan pelaku atau informasi dari tangan pertama. Data primer diperoleh dari wawancara atau questioner terhadap responden (Silalahi, 2010). Kuesioner adalah sejumlah pertanyaan tertulis yang digunakan untuk memperoleh informasi dari responden dalam arti laporan tentang pribadinya atau hal-hal yang diketahui (Arikunto, 2006). Populasi 
yang digunakan dalam penelitian ini berjumlah 285 konter pulsa. Menurut Sugiyono (2011), populasi adalah wilayah generalisasi yang terdiri atas objek atau subjek yang mempunyai kualitas dan karakteristik tertentu yang ditetapkan oleh peneliti untuk dipelajari dan kemudian ditarik kesimpulannya. Sampel adalah semua obyek atau gejala atau kejadian atau peristiwa tetapi hanya sebagian saja atau wakil populasi yang diteliti (Masyhuri dan Zainuddin, 2008). Pengambilan sampel menggunakan rumus Slovin dari populasi konter pulsa dan paket data di Kecamatan Tungkal Ilir adalah sebanyak 285 kios pulsa dan paket data yaitu sebagai berikut (Firdaus, 2011) :

$S=\frac{\mathrm{N}}{1+\mathrm{N} \cdot \mathrm{e}^{2}}$

$S=\frac{285}{1+285 \cdot(0,1)^{2}}$

$S=\frac{285}{1+2,85}$

$S=\frac{285}{3,85}$

$S=74,03$ (di bulatkan menjadi 74 responden)

Regresi linier berganda digunakan ntuk menganalisis pengaruh modal, harga, jumlah kredit dan volume penjualan terhadap pendapatan maka digunakan rumus regresi linier berganda dalam bentuk persamaan sebagai berikut (Firdaus,2011):

$$
\mathbf{Y}=\mathbf{a}+\mathbf{b}_{1} \mathbf{X}_{1}+\mathbf{b}_{2} \mathbf{X}_{2}+\ldots \ldots . \mathbf{b}_{\mathbf{n}} \mathbf{X}_{\mathbf{n}}
$$

Selanjutnya model analisis regresi linier berganda tersebut ditransformasikan secara operasional sesuai dengan variabel penelitian sebagai berikut:

$$
\boldsymbol{Y}=\boldsymbol{\beta}_{0}+\boldsymbol{\beta}_{1} \boldsymbol{M}+\boldsymbol{\beta}_{2} \mathbf{T H}++\boldsymbol{\beta}_{3} \mathrm{JP}+\boldsymbol{\beta}_{4} \mathbf{V P}+\boldsymbol{\mu}
$$

Keterangan:

$\mathrm{Y}=$ Pendapatan pedagang pulsa dan paket data $(\mathrm{Rp})$

$\mathrm{M} \quad=$ Modal $(\mathrm{Rp})$

$\mathrm{TH}=$ Total harga $(\mathrm{Rp})$

$\mathrm{JP} \quad=$ Jumlah saldo pulsa $(\mathrm{Rp})$

$\mathrm{VP} \quad=$ Volume penjualan

$\beta_{0} \quad=$ Konstanta

$\beta_{1}, \beta_{2}, \beta_{3}, \beta_{4} \quad=$ Koefisien

$\mu \quad=$ disturbance term

\section{Uji signifikansi parameter individual (Uji t)}

Uji Signifikansi Parameter Individual (Uji t) ini bertujuan untuk mencari pengaruh variable-variabel terhadap pendapatan apakah berpengaruh positif atau berpengaruh negatif, dengan rumus sebagai berikut (Firdaus, 2011):

$$
\mathrm{t}=\frac{\beta \mathrm{i}}{\operatorname{Se}(\beta \mathrm{i})}
$$

Keterangan:

$\beta \mathrm{i}=$ Koefisien regresi

$\mathrm{Se}(\beta \mathrm{i})=$ Standart error koefisien regresi 
Sedangkan kriteria pengujiannya adalah apabila $\mathrm{t}$ hitung $>\mathrm{t}$ tabel, maka Ho ditolak dan Hi diterima dan apabila t hitung < t tabel, maka Ho diterima dan Hi ditolak.

\section{Uji signifikansi parameter serentak (Uji F)}

Uji Signifikansi Parameter Serentak (Uji F) ini bertujuan untuk mencari pengaruh variable-variabel secara serentak terhadap pendapatan apakah berpengaruh positif atau berpengaruh negatif, dengan rumus sebagai berikut (Firdaus, 2011):

Fhitung $=\frac{R^{2}(n-k-1)}{k\left(1-R^{2}\right)}$

Keterangan:

$\mathrm{R}^{2}=$ Koefisien determinasi

$\mathrm{N} \quad=$ Jumlah sample

$\mathrm{K}=$ jumlah variabel

Kriteria pengujian:

Jika $\mathrm{t}_{\text {hitung }}>\mathrm{t}_{\text {tabel }}$ maka $\mathrm{H}_{0}$ ditolak

Jika $t_{\text {hitung }}<\mathrm{t}_{\text {tabel }}$ maka $\mathrm{H}_{0}$ diterima

Kesimpulan nya jika $t_{\text {hitung }}>t_{\text {tabel }}$ maka $\mathrm{H}_{0}$ ditolak, berarti terdapat pengaruh yang signifikan antara variabel bebas terhadap variabel terikat, dan sebaliknya apabila $t_{\text {hitung }}<$ $\mathrm{t}_{\text {tabel }}$ maka $\mathrm{H}_{0}$ diterima, artinya tidak terdapat pengaruh yang signifikan terhadap variabel bebas dan terikat.

\section{Koefisien determinan $\left(\mathbf{R}^{2}\right)$}

Koefisien determinan bertujuan untuk mengetahui seberapa jauh kemampuan model regresi dalam menerangkan variabel dari variabel terikat (Suliyanto, 2011).

\section{Uji asumsi klasik}

Suatu model dikatakan cukup baik dan dapat dipakai untuk memprediksi apabila sudah lolos dari serangkaian uji asumsi klasik yang melandasinya.

\section{Uji multikoliniaritas}

Multikolinearitas adalah situasi adanya korelasi variabel-variabel independen di antara satu dengan lainnya. Uji multikolinearitas bertujuan untuk menguji apakah dalam model regresi ditemukan adanya korelasi antara variabel independen. Model regresi yang baik seharusnya tidak terjadi korelasi diantara variabel independen. (Kuncoro, 2013)

\section{Uji heteroskedastisitas}

Heteroskedastisitas adalah variansi data yang digunakan untuk membuat model menjadi tidak konstan. Pengujian terhadap ada tidaknya masalah heteroskedastisitas dalam suatu model empiris yang sedang diamati juga merupakan langkah penting sehingga dapat terhindar dari masalah regresi lancung. Metode untuk dapat mendeteksi ada tidaknya masalah heteroskedastisitas dalam model empiris dengan menggunakan uji White (Insukindro, 2003).

\section{Uji autokorelasi}

Autokorelasi adalah terjadinya korelasi antara variabel itu sendiri pada pengamatan yang berbeda. Pengujian autokorelasi dilakukan dengan uji BreuschGodfrey Serial Correlation Lagrange Multiplier Test (uji LM). Uji ini sangat 
berguna untuk mengidentifikasi masalah autokorelasi tidak hanya pada derajat pertama tetapibisa juga digunakan pada tingkat derajat. Dikatakan terjadi autokorelasi jika nilai X2 (Obs* R-Squared) hitung > X2 tabel atau nilai Probability < derajat kepercayaan yang ditentukan (Insukindro, 2003).

\section{HASIL DAN PEMBAHASAN}

\section{Karakteristik responden berdasarkan umur}

Semakin tinggi usia pedagang pedagang pulsa dan paket data maka semakin berkurang tingkat produktivitas dari usaha tersebut sebaliknya semakin muda usia pedagang pulsa dan paket data maka semakin meningkat tingkat produktivitas pasar tersebut. Dilain pihak, semakin tinggi usia pedagang pulsa dan paket data maka pengalaman usaha akan semakin bertambah. Secara rinci, usia pedagang pasar dapat dilihat pada Tabel 1.

Tabel 1. Distribusi responden berdasarkan umur

\begin{tabular}{ccccc}
\hline No & $\begin{array}{c}\text { Umur } \\
\text { (Tahun) }\end{array}$ & $\begin{array}{c}\text { Rata-Rata Umur } \\
\text { (Tahun) }\end{array}$ & $\begin{array}{c}\text { Jumlah } \\
\text { (Orang) }\end{array}$ & $\begin{array}{c}\text { Persentase } \\
(\mathbf{\%})\end{array}$ \\
\hline 1 & $21-23$ & 22 & 11 & 14,86 \\
2 & $24-26$ & 25 & 23 & 31,08 \\
3 & $27-29$ & 28 & 8 & 10,81 \\
4 & $30-32$ & 31 & 9 & 12,16 \\
5 & $33-35$ & 34 & 16 & 21,62 \\
6 & $36-38$ & 37 & 5 & 6,76 \\
7 & $39-41$ & 40 & 2 & 2,70 \\
\hline & Total & & $\mathbf{7 4}$ & $\mathbf{1 0 0 . 0 0}$ \\
\hline
\end{tabular}

Sumber: Data diolah, 2020

Usia pedagang pulsa dan paket data terbanyak berada pada usia 24-26 tahun yaitu sebanyak 23 orang atau sekitar 31,08\% dengan rata-rata umur adalah 25 tahun. Hal ini dikarenakan usia tersebut merupakan usia yang ideal bagi pedagang pulsa dan paket data akibat dari meningkatkanya pengalaman dalam mengelola usaha. Berdasarkan data tersebut juga terlihat bahwa usia pedagang pulsa dan paket data paling sedikit berada pada umur 39-41 tahun yaitu sebanyak 2 orang atau 2,70\%.

\section{Karakteristik responden berdasarkan jenis kelamin}

Jenis kelamin pedagang pasar menentukan seberapa lama pedagang pasar mampu membuka usaha per harinya. Biasanya jenis kelamin laki-laki cenderung membuka usaha pasar lebih lama dibandingkan perempuan. Hal ini dikarenakan laki-laki merupakan kepala keluarga yang wajib dalam usaha menafkahi keluarga. Sedangkan kaum perempuan akan memiliki sedikit waktu dalam membuka usaha pasar sebab kaum perempuan terutama yang sudah menikah harus mengerjakan pekerjaan rumah tangga dalam keluarga. Distribusi frekuensi jenis kelamin pedagang manisan dapat dilihat pada Tabel 2:

Tabel 2. Distribusi responden berdasarkan jenis kelamin

\begin{tabular}{cccc}
\hline No & Jenis Kelamin & $\begin{array}{c}\text { Jumlah } \\
\text { (Orang) }\end{array}$ & $\begin{array}{c}\text { Persentase } \\
(\boldsymbol{\%})\end{array}$ \\
\hline 1 & Laki-Laki & 58 & 78,38 \\
2 & Perempuan & 16 & 21,62 \\
\hline & Total & $\mathbf{7 4}$ & $\mathbf{1 0 0 , 0 0}$
\end{tabular}

Sumber: Data diolah, 2020 
Berdasarkan Tabel 2 terlihat bahwa pedagang pulsa dan paket data yang berjenis kelamin laki-laki adalah sebanyak 58 orang atau sebesar $78,38 \%$ dibandingkan dengan pedagang pulsa dan paket data yang berjenis kelamin perempuan yang sebnayak 16 orang atau $21,62 \%$. Jumlah perempuan yang sedikit menekuni usaha ini karena perempuan lebih memilih untuk bekerja sebagai pegawai di konter-konter pulsa atau pekerjaan lainnya.

\section{Karakteristik responden berdasarkan tingkat pendidikan}

Tingkat pendidikan merupakan ukuran kemampuan seseorang untuk mengelola dan menganalisa potensi usaha dalam menghadapi persaingan usaha. Semakin tinggi tingkat pendidikan maka semakin tinggi pula kemampuan pedagang pulsa dan paket data dalam bersaing dalam dunia usaha. Namun, terkadang walaupun tingkat pendidikan tinggi tidak menjamin pendapatan akan semakin meningkat. Hal ini disebabkan karena keterbatasan modal yang menjadi kendala dalam mengembangkan usaha pulsa dan paket data. Distribusi frekuensi tingkat pendidikan pasar dapat dilihat pada Tabel 3.

Tabel 3. Distribusi responden berdasarkan tingkat pendidikan

\begin{tabular}{cccc}
\hline No & $\begin{array}{c}\text { Tingkat } \\
\text { pendidikan }\end{array}$ & $\begin{array}{c}\text { Jumlah } \\
\text { (orang) }\end{array}$ & $\begin{array}{c}\text { Persentase } \\
(\boldsymbol{\%})\end{array}$ \\
\hline 1 & SMP & 3 & 4,05 \\
2 & SMA & 56 & 75,68 \\
3 & S1 & 15 & 20,27 \\
\hline & Total & 74 & 100,00 \\
\hline
\end{tabular}

Sumber: Data diolah, 2020

Berdasarkan Tabel 3, terlihat bawa tingkat pendidikan SMA merupakan tingkat pendidikan terbanyak diantara para pedagang pulsa dan paket data. Banyaknya tingkat pendidikan SMA dikalangan para pedagang tidak lepas dari campur tangan pemerintah dalam dunia pendidikan melalui program beasiswa maupun program pendukung lainnya. Tingkat pendidikan S1 merupakan tingkat pendidikan terbanyak kedua.

\section{Karakteristik responden berdasarkan status perkawinan}

Status perkawinan "Belum Kawin" biasanya akan mampu mengembangkan usahanya dikarenakan hasil pendapatan dapat dijadikan sebagai modal untuk pengembangan usaha sedangkan status perkawinan "Kawin" akan memiliki kendala dalam pengembangan usaha dikarenakan pendapatan dari usaha digunakan untuk kebutuhan dan biaya hidup sehari-hari. Kerincian status perkawinan pedagang pulsa dan paket data dapat dilihat pada Tabel 4 .

Tabel 4. Distribusi responden berdasarkan status perkawinan

\begin{tabular}{llcc}
\hline No & Status perkawinan & $\begin{array}{c}\text { Jumlah } \\
\text { (orang) }\end{array}$ & $\begin{array}{c}\text { Persentase } \\
(\boldsymbol{\%})\end{array}$ \\
\hline 1 & Belum kawin & 24 & 32,43 \\
2 & Kawin & 50 & 67,57 \\
\hline \multicolumn{2}{c}{ Total } & $\mathbf{7 4}$ & $\mathbf{1 0 0 , 0}$ \\
\hline
\end{tabular}

Sumber: Data diolah, 2020

Berdasarkan Tabel 4, status perkawinan pedagang pulsa dan paket data terbanyak adalah status "Kawin". Hal ini dikarenakan banyak pedagang pulsa dan paket data beranggapan bahwa rezeki datang setelah menikah. Para pedagang yang sudah menikah 
beranggapan bahwa apabila sudah menikah maka pendapatan keluarga akan meningkat dikarenakan yang bekerja untuk menghasilkan pendapatan juga mengalami peningkatan.

\section{Karakteristik responden berdasarkan jumlah tanggungan keluarga}

Semakin banyak anggota keluarga maka biaya untuk kebutuhan hidup akan semakin tinggi sebaliknya semakin sedikit anggota keluarga maka biaya untuk kebutuhan hidup akan semakin rendah. Disamping itu, semakin banyak anggota keluarga maka usaha akan lebih terbantu akibat dari penghematan biaya gaji tenaga kerja. Kerincian jumlah tanggungan keluarga dapat dilihat pada Tabel 5:

Tabel 5. Distribusi responden berdasarkan jumlah tanggungan keluarga

\begin{tabular}{cccc}
\hline No & $\begin{array}{c}\text { Jumlah tanggungan } \\
\text { Keluarga (Orang) }\end{array}$ & $\begin{array}{c}\text { Jumlah } \\
\text { (Orang) }\end{array}$ & $\begin{array}{c}\text { Persentase } \\
(\mathbf{\%})\end{array}$ \\
\hline 1 & 0 & 24 & 32,43 \\
2 & 1 & 11 & 14,86 \\
3 & 2 & 24 & 32,43 \\
4 & 3 & 15 & 20,27 \\
& Total & 74 & 100,00 \\
\hline
\end{tabular}

Sumber: Data diolah, 2020

Berdasarkan Tabel 5, jumlah tanggungan keluarga dengan pedagang pulsa dan paket data terbanyak adalah 24 anggota keluarga yaitu sebesar 0 orang dan 2 orang pedagang pulsa dan paket data yaitu sebanyak 24 orang atau 32,43\%. Jumlah tanggungan 0 orang berarti pedagang pulsa dan paket data tersebut belum menikah sehingga tidak memiliki jumlah tanggungan karena belum kawin ataupun baru menikah namun belum memiliki anak. Jumlah tanggungan keluarga dengan pedagang pulsa dan paket data terbanyak kedua adalah 3 orang yaitu sebanyak 15 orang atau 20,27\% dimana pedagang ini telah lama kawin sedangkan jumlah tanggungan keluarga dengan pedagang pulsa dan paket data paling sedikit adalah 1 orang yaitu sebanyak 11 orang atau 14,86\% karena pernikahannya baru berumur 1 tahun atau lebih.

\section{Karakteristik responden berdasarkan sumber distributor pulsa}

Sumber distributor pulsa bisa berasal dari all operator (agen semua operator) atau aplikasi online (Shopee, Tokopedia, Bukalapak, dan lain-lain) yang menyediakan jasa isi ulang pulsa. frekuensi sumber distributor pulsa dapat dilihat pada Tabel 6:

Tabel 6. Distribusi responden berdasarkan sumber distributor pulsa

\begin{tabular}{cccc}
\hline No & Sumber distributor pulsa & $\begin{array}{c}\text { Jumlah } \\
\text { (Orang) }\end{array}$ & $\begin{array}{c}\text { Persentase } \\
(\boldsymbol{\%})\end{array}$ \\
\hline 1 & All Operator & 58 & 78,38 \\
2 & Aplikasi Online & 16 & 21,62 \\
& Total & 74 & 100,00 \\
\hline
\end{tabular}

Sumber: Data diolah, 2020

Berdasarkan Tabel 6 dapat dilihat bahwa pedagang pulsa dan paket data lebih banyak mengambil dari All Operator (Agen Langsung) yaitu sebanyak 58 orang atau $78,38 \%$ sedangkan pedagang yang mengambil dari aplikasi online sebnayak 16 orang atau 21,62\%. Hal ini dikarenakan tingkat kepercayaan terhadap All Operator (Agen Langsung) lebih tinggi dibandingkan terhadap aplikasi online. Selain itu, bagi para pedagang all operator lebih baik karena pulsa dan paket data bisa dikredit sedangkan aplikasi online harus menyetor dana terlebih dahulu baru bisa melakukan transaksi 
pulsa. Namun, dilihat dari harga perolehan pulsa aplikasi online harga pulsanya lebih murah dibandingkan dengan harga di all operator.

\section{Karakteristik responden berdasarkan modal usaha}

Modal usaha para pedagang pulsa dan paket data biasanya dikonversi ke dalam bentuk saldo pulsa atau vocer fisik kuota internet (paket data) sebagai barang untuk diperjualbelikan. vocer fisik kuota internet berasal dari berbagai macam provider seperti Telkomsel, XL, Smartfren maupun Tri yang memiliki kuota internet yang berbeda-beda dengan harga yang berbeda pula. Distribusi frekuensi modal usaha dapat dilihat pada Tabel 7:

Tabel 7. Distribusi responden berdasarkan modal usaha

\begin{tabular}{cccc}
\hline No & $\begin{array}{c}\text { Modal Usaha } \\
\text { (Rupiah) }\end{array}$ & $\begin{array}{c}\text { Jumlah } \\
\text { (Orang) }\end{array}$ & $\begin{array}{c}\text { Persentase } \\
(\mathbf{\%})\end{array}$ \\
\hline 1 & $1.800 .000-2.657 .142$ & 5 & 6,76 \\
2 & $2.657 .143-3.514 .285$ & 24 & 32,43 \\
3 & $3.514 .286-4.371 .428$ & 18 & 24,32 \\
4 & $4.371 .429-5.228 .570$ & 17 & 22,97 \\
5 & $5.228 .571-6.085 .713$ & 8 & 10,81 \\
6 & $6.085 .714-6.942 .856$ & 4 & 5,13 \\
7 & $6.942 .857-7.800 .000$ & 2 & 2,70 \\
\hline & Total & $\mathbf{7 4}$ & $\mathbf{1 0 0 , 0 0}$ \\
\hline
\end{tabular}

Sumber: Data diolah, 2020

Berdasarkan pada Tabel 7 terlihat bahwa modal usaha dengan pedagang pulsa dan paket data terbanyak berada pada kisaran Rp. 2.657.143 - Rp. 3.514.285 yaitu sebanyak 24 orang atau $32,43 \%$. Selanjutnya, modal usaha dengan pedagang pulsa dan paket data terbanyak kedua berada pada kisaran Rp. 3.514.286 - Rp. 4.371 .428 yaitu sebanyak 18 orang atau $24,32 \%$. Sedangkan, modal usaha dengan pedagang pulsa dan paket data paling sedikit berada pada kisaran Rp. 6.942 .857 - Rp. 7.800 .000 yaitu sebanyak 2 orang atau $2,70 \%$.

\section{Karakteristik responden berdasarkan harga pulsa dan paket data}

Harga pulsa biasanya memiliki selisih sebesar dua ribu rupiah dari pulsa nominalnya sedangkan harga paket data disesuaikan dengan harga dari provider. Khusus untuk paket data, harga dari provider yang satu dengan yang lain akan berbeda walaupun jumlah kuota paket data sama. Distribusi frekuensi harga dan paket data dapat diliat pada Tabel 8:

Tabel 8. Distribusi responden berdasarkan harga dan paket data

\begin{tabular}{cccc}
\hline No & $\begin{array}{c}\text { Harga dan Paket Data } \\
\text { (Rupiah) }\end{array}$ & $\begin{array}{c}\text { Jumlah } \\
\text { (Orang) }\end{array}$ & $\begin{array}{c}\text { Persentase } \\
(\mathbf{\%})\end{array}$ \\
\hline 1 & $581.000-1.096 .428$ & 38 & 51,35 \\
2 & $1.096 .429-1.611 .857$ & 6 & 8,11 \\
3 & $1.611 .858-2.127 .286$ & 14 & 18,92 \\
4 & $2.127 .287-2.642 .715$ & 0 & 0,00 \\
5 & $2.642 .716-3.158 .144$ & 0 & 0,00 \\
6 & $3.158 .145-3.673 .573$ & 3 & 4,05 \\
7 & $3.673 .574-4.189 .002$ & 13 & 17,57 \\
\hline \multicolumn{2}{c}{ Total } & $\mathbf{7 4}$ & $\mathbf{1 0 0 , 0 0}$
\end{tabular}

Sumber: Data diolah, 2020 
Berdasarkan Tabel 8, harga dan paket data dengan responden terbanyak berada di kisaran Rp. 581.000 - Rp. 1.096 .428 yaitu sebanyak 38 orang atau 51,35\% sedangkan harga dan paket data dengan responden terbanyak berada di kisaran Rp. 3.158.145 - Rp. 3.673.573 yang hanya sebanyak 3 orang atau $4,05 \%$. harga dan paket data pada kisaran Rp. 581.000 - Rp. 1.096.428 lebih banyak karena pulsa dan paket data yang sediakan untuk diperjualbelikan merupakan pulsa dan paket data yang paling banyak dibeli oleh konsumen.

\section{Karakteristik responden berdasarkan jumlah saldo pulsa}

Jumlah saldo pulsa para pedagang biasanya disesuaikan dengan jumlah pengisian yang dilakukan oleh konsumen per bulannya. Kerincian jumlah saldo pulsa terlihat pada Tabel 9:

Tabel 9. Disrtribusi responden berdasarkan jumlah saldo pulsa

\begin{tabular}{cccc}
\hline No & $\begin{array}{c}\text { Jumlah saldo pulsa } \\
\text { (Rupiah) }\end{array}$ & $\begin{array}{c}\text { Jumlah } \\
\text { (Orang) }\end{array}$ & $\begin{array}{c}\text { Persentase } \\
(\boldsymbol{\%})\end{array}$ \\
\hline 1 & $100.000-171.428$ & 20 & 27,03 \\
2 & $171.429-242.856$ & 13 & 17,57 \\
3 & $242.857-314.285$ & 24 & 32,43 \\
4 & $314.286-385.713$ & 4 & 5,41 \\
5 & $385.714-457.143$ & 6 & 8,11 \\
6 & $457.143-528.570$ & 6 & 8,11 \\
7 & $528.571-600.000$ & 1 & 1,35 \\
\hline & Total & $\mathbf{7 4}$ & $\mathbf{1 0 0 , 0 0}$ \\
\hline
\end{tabular}

Sumber: Data diolah, 2020

Berdasarkan Tabel 9, jumlah saldo pulsa dengan pedagang pulsa dan paket data terbanyak adalah Rp. 242.857 - Rp. 314.285 yaitu sebanyak 24 orang atau 32,43\%. Jumlah saldo pulsa dengan pedagang pulsa dan paket data terbanyak kedua adalah Rp 100.000 - Rp. 171.428 yaitu sebanyak 20 orang atau 27,03\%. Jumlah saldo pulsa dengan pedagang pulsa dan paket data paling sedikit adalah Rp 528.571 - Rp 600.000 sebanyak 1 orang atau $1,35 \%$.

\section{Karakteristik responden berdasarkan volume penjualan paket data}

Jumlah penjualan paket data per harinya tentu saja bervariasi. Hal ini disebabkan karena konsumen atau pembeli akan cenderung membeli paket data yang melimpah dengan harga yang lebih murah. Kerincian Volume penjualan paket data terlihat pada Tabel 10.

Tabel 10. Disrtribusi Responden Berdasarkan Volume Penjualan Paket Data

\begin{tabular}{cccc}
\hline No & $\begin{array}{c}\text { Volume Penjualan Paket Data } \\
\text { (Unit) }\end{array}$ & $\begin{array}{c}\text { Jumlah } \\
\text { (Orang) }\end{array}$ & $\begin{array}{c}\text { Persentase } \\
(\boldsymbol{\%})\end{array}$ \\
\hline 1 & $3-5$ & 4 & 5,41 \\
2 & $6-8$ & 36 & 48,65 \\
3 & $9-11$ & 19 & 25,68 \\
4 & $12-14$ & 10 & 13,51 \\
5 & $15-17$ & 2 & 2,70 \\
6 & $18-20$ & 2 & 2,70 \\
7 & $21-23$ & 1 & 1,35 \\
& & 74 & 100.0 \\
\hline
\end{tabular}

Sumber: Data diolah, 2020 
Berdasarkan Tabel 10 terlihat bahwa volume penjualan paket data dengan responden terbanyak adalah 6-8 unit yaitu sebanyak 36 orang atau 48,65\%. volume penjualan paket data dengan responden terbanyak kedua adalah 9-11 unit yaitu sebanyak 19 orang atau 25,68\%. Hal ini menandakan bahwa volume penjualan paket data pedagang pulsa dan paket data lebih sering terjual sebanyak 6-8 unit dan 9-11 unit paket data per harinya.

Pengaruh Modal, Harga Produk yang Dijual, Jumlah Saldo Pulsa dan Volume Penjualan Paket Data terhadap Pendapatan Pedagang Pulsa dan Paket Data di Kecamatan Tungkal Ilir Kabupaten Tanjung Jabung Barat

Regresi linier berganda merupakan alat analisis yang digunakan untuk melihat pengaruh antara modal, harga produk yang dijual, jumlah saldo pulsa dan volume penjualan paket data terhadap pendapatan pedagang pulsa dan paket data di Kecamatan Tungkal Ilir Kabupaten Tanjung Jabung Barat. Hasil regresi linier berganda dapat dilihat pada Tabel 11.

Tabel 11. Hasil regresi linier berganda

\begin{tabular}{|c|c|c|c|c|}
\hline \multirow{2}{*}{$\begin{array}{c}\text { Dependent Variable } \\
\text { Variable }\end{array}$} & \multicolumn{4}{|c|}{$\mathbf{Y}$} \\
\hline & Coefficient & Std. Error & t-Statistic & Prob. \\
\hline $\mathrm{C}$ & $541.402,4$ & 119010,0 & 4,549217 & 0,0000 \\
\hline $\mathrm{M}$ & 0,932089 & 0,054610 & 17,06824 & 0,0000 \\
\hline $\mathrm{TH}$ & 0,002195 & 0,027333 & 0,080304 & 0,9362 \\
\hline JP & 0,057948 & 0,236291 & 0,245238 & 0,8070 \\
\hline VP & $42.748,54$ & 21235,20 & 2,013098 & 0,0480 \\
\hline \multirow[t]{2}{*}{ R-squared } & \multicolumn{2}{|c|}{ 0,965702F-statistic } & & 485,6926 \\
\hline & \multicolumn{2}{|c|}{ Prob(F-statistic) } & & 0,000000 \\
\hline
\end{tabular}

Sumber: Data diolah, 2020

Berdasarkan Tabel 11, persamaan regresi linier berganda yang diperoleh dengan pengolahan data menggunakan eviews 9 adalah:

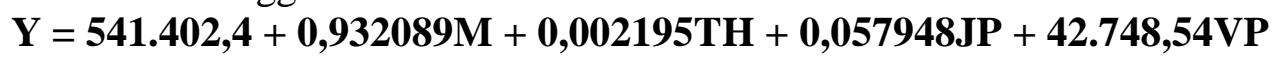

Persamaan tersebut dapat diinterprestasikan apabila modal $(\mathrm{M})$, harga produk yang dijual (TH), jumlah saldo pulsa (JP) dan volume penjualan paket data (VP) bersifat tetap atau konstan maka pendapatan pedagang pulsa dan paket data di Kecamatan Tungkal Ilir Kabupaten Tanjung Jabung Barat (Y) akan mengalami peningkatan sebanyak Rp. 541.402,4,-. Hal ini terlihat dari nilai konstanta persamaan regresi (C) adalah sebesar 541.402,4 dan bertanda positif.

Koefisien regresi variabel modal (M) bernilai 0,932089 dan bertanda positif artinya apabila terjadi peningkatan modal sebesar Rp. 1,- maka pendapatan pedagang pulsa dan paket data di Kecamatan Tungkal Ilir Kabupaten Tanjung Jabung Barat (Y) akan meningkat sebesar Rp. 0,932089,-. Hal ini dikarenakan apabila modal meningkat maka jumlah saldo pulsa dan jumlah paket data yang akan ditransaksikan akan mengalami peningkatan pula.

Koefisien regresi variabel harga produk yang dijual (TH) bernilai 0,002195 dan bertanda positif. Hal ini berarti bahwa apabila terjadi peningkatan harga produk yang dijual (TH) sebesar Rp. 1,- maka pendapatan pedagang pulsa dan paket data di Kecamatan Tungkal Ilir Kabupaten Tanjung Jabung Barat (Y) akan meningkat sebesar Rp. 0,002195,-. 
Koefisien regresi variabel jumlah saldo pulsa (JP) bernilai 0,057948 dan bertanda positif. Hal ini berarti bahwa apabila terjadi peningkatan jumlah saldo pulsa (JP) sebesar Rp. 1,- maka pendapatan pedagang pulsa dan paket data di Kecamatan Tungkal Ilir Kabupaten Tanjung Jabung Barat (Y) akan meningkat sebesar Rp. 0,057948,-.

Koefisien regresi variabel volume penjualan paket data (VP) bernilai 42.748,54 dan bertanda positif. Hal ini berarti bahwa apabila terjadi peningkatan volume penjualan paket data (VP) sebesar 1 unit maka pendapatan pedagang pulsa dan paket data di Kecamatan Tungkal Ilir Kabupaten Tanjung Jabung Barat (Y) akan meningkat sebesar Rp. 42.748,54,-.

\section{Pengujian hipotesis}

\section{Pengujian hipotesis secara serentak (Uji-F)}

Pengujian hipotesis secara serentak atau Uji-F digunakan untuk melihat pengaruh secara bersama-sama variabel modal (M), harga produk yang dijual (TH), jumlah saldo pulsa (JP) dan volume penjualan paket data (VP) terhadap variabel pendapatan pedagang pulsa dan paket data di Kecamatan Tungkal Ilir Kabupaten Tanjung Jabung Barat (Y). Hasil regresi linier berganda dengan menggunakan Eviews 9.0 pada tabel 5.11 menunjukkan bahwa nilai F-statistik sebesar 485,6926 dengan probabilita sama dengan 0.000000. Nilai probabilitas F-statistik 0.000000 lebih kecil dibandingkan dengan tingkat Alpha 0.05. Dengan demikian dapat disimpulkan bahwa variabel modal (M), harga produk yang dijual (TH), jumlah saldo pulsa (JP) dan volume penjualan paket data (VP) berpengaruh signifikan secara bersama-sama (simultan) terhadap variabel pendapatan pedagang pulsa dan paket data di Kecamatan Tungkal Ilir Kabupaten Tanjung Jabung Barat (Y).

\section{Pengujian hipotesis secara parsial (Uji-t)}

Nilai dalam uji-t ditentukan dengan membandingkan tingkat probabilitas dengan tingkat Alpha 0,05. Nilai probabilitas variabel Modal (M) adalah sebesar 0.000 lebih kecil dibandingkan dengan tingkat Alpha 0,05. Hal ini berarti variabel Modal (M) memiliki pengaruh yang signifikan terhadap variabel pendapatan pedagang pulsa dan paket data di Kecamatan Tungkal Ilir Kabupaten Tanjung Jabung Barat (Y). Nilai probabilitas variabel harga produk yang dijual $(\mathrm{TH})$ adalah sebesar 0,9362 lebih tinggi dari tingkat alpha 0,05. Hal ini berarti variabel harga produk yang dijual $(\mathrm{TH})$ tidak memiliki pengaruh yang signifikan terhadap variabel pendapatan pedagang pulsa dan paket data di Kecamatan Tungkal Ilir Kabupaten Tanjung Jabung Barat (Y). Nilai probabilitas variabel jumlah saldo pulsa (JP) adalah sebesar 0,8070 lebih tinggi dari tingkat alpha 0,05. Hal ini berarti variabel jumlah saldo pulsa (JP) tidak memiliki pengaruh yang signifikan terhadap variabel pendapatan pedagang pulsa dan paket data di Kecamatan Tungkal Ilir Kabupaten Tanjung Jabung Barat (Y). Nilai probabilitas variabel volume penjualan paket data (VP) adalah sebesar 0,0480 lebih rendah dari tingkat alpha 0,05 . Hal ini berarti variabel volume penjualan paket data (VP) memiliki pengaruh yang signifikan terhadap variabel pendapatan pedagang pulsa dan paket data di Kecamatan Tungkal Ilir Kabupaten Tanjung Jabung Barat (Y).

\section{Koefisien determinasi $\left(\mathbf{R}^{2}\right)$}

Koefisien determinasi $\left(\mathrm{R}^{2}\right)$ bernilai 0,965702 . Nilai tersebut berarti sebanyak 96,5702\% kemampuan variabel modal (M), harga produk yang dijual (TH), jumlah saldo pulsa (JP) dan volume penjualan paket data (VP) mampu untuk menjelaskan 
variabel pendapatan pedagang pulsa dan paket data di Kecamatan Tungkal Ilir Kabupaten Tanjung Jabung Barat (Y) sedangkan sisanya 3,4298\% dipengaruhi oleh variabel lain diluar model.

\section{Uji asumsi klasik}

\section{Uji multikolinieritas}

Model regresi dikatakan tidak mengandung multikolinieritas apabila nilai VIF berada dibawah 5 atau 10. Tabel 5.11 menunjukkan bahwa nilai VIF dari variabel modal (M), harga produk yang dijual (TH), jumlah saldo pulsa (JP) dan volume penjualan paket data (VP) kurang dari 10, artinya antara satu variabel bebas dengan variabel bebas lainnya tidak saling mempengaruhi. Artinya, model regresi tidak mengandung multikolinieritas.

Tabel 12. Uji multikolinieritas

\begin{tabular}{cccc}
\hline Variable & $\begin{array}{c}\text { Coefficient } \\
\text { Variance }\end{array}$ & $\begin{array}{c}\text { Uncentered } \\
\text { VIF }\end{array}$ & $\begin{array}{c}\text { Centered } \\
\text { VIF }\end{array}$ \\
\hline C & $1.42 \mathrm{E}+10$ & 17.78958 & NA \\
M & 0.002982 & 66.91541 & 5.476103 \\
TH & 0.000747 & 3.855770 & 1.337240 \\
JP & 0.055834 & 5.828244 & 1.008385 \\
VP & $4.51 \mathrm{E}+08$ & 51.34965 & 5.058261 \\
\hline
\end{tabular}

Sumber: Data diolah, 2020

\section{Uji autokorelasi}

Autokorelasi dapat dilihat dengan Uji Breusch-Godfrey yaitu dengan membandingkan Prob. Chi-Square hitung dengan tingkat alpha 5\%. Model regresi dikatakan terbebas dari autokorelasi apabila nilai Chi-Square hitung lebih besar dari tingkat alpha 5\%.. Tabel 14 menunjukkan bahwa nilai Prob. Chi-Square hitung sebesar 0.1085 lebih besar dari tingkat alpha 5\%. Hal ini berarti model regresi lolos dari adanya autokorelasi.

Tabel 13. Uji autokorelasi

Breusch-Godfrey Serial Correlation LM Test:

\begin{tabular}{llll}
\hline F-statistic & 2.452216 & Prob. F(1,68) & 0.1220 \\
Obs*R-squared & 2.575703 & Prob. Chi-Square $(1)$ & 0.1085 \\
\hline
\end{tabular}

Sumber: Data diolah, 2020

\section{Uji heterokedastisitas}

Heteroskedastisitas merupakan masalah regresi yang faktor gangguannya tidak memiliki varian yang sama atau variannya tidak konstan. Uji heterokedastisitas dalam penelitian ini menggunakan uji Glejser. Tabel 15 menunjukkan bahwa nilai Prob. Obs*R-squared (Chi-Square hitung) sebesar 0,5287 lebih besar dari tingkat alpha 5\%. Hal ini berarti model regresi lolos dari adanya heterokedastisitas.

Tabel 14. Uji heterokedastis

\begin{tabular}{llll}
\hline Heteroskedasticity Test: Glejser & & \\
\hline F-statistic & 0.773720 & Prob. F(4,69) & 0.5460 \\
Obs*R-squared & 3.176663 & Prob. Chi-Square(4) & 0.5287 \\
Scaled explained SS & 4.036639 & Prob. Chi-Square(4) & 0.4011 \\
\hline
\end{tabular}

Sumber: Data diolah, 2020 


\section{Analisis ekonomi}

Berdasarkan hasil penelitian diketahui bahwa modal memiliki pengaruh yang positif dan signifikan terhadap pendapatan pedagang pulsa dan paket data. Hal ini berarti bahwa apabila terjadi peningkatan pada modal maka pendapatan pedagang pulsa dan paket data juga akan mengalami peningkatan. Jumlah pendapatan yang akan meningkat setiap peningkatan modal sebesar satu juta rupiah adalah 932.089 rupiah yang terlihat dari nilai yang positif pada koefisien regresi pada variabel modal. Hal ini disebabkan karena semakin besar modal yang digunakan maka saldo pulsa dan paket data yang akan ditransaksikan akan semakin banyak.

Hasil penelitian menunjukkan bahwa harga produk yang dijual memiliki pengaruh yang positif namun tidak signifikan terhadap pendapatan pedagang pulsa dan paket data. Ketidaksignifikansi variabel harga produk yang dijual terlihat dari nilai probabilita tstatistik yang lebih besar dibandingkan tingkat alpha 5\%. Hal ini berarti walaupun terjadi peningkatan pada harga produk yang dijual, peningkatan pendapatan yang terjadi pada pedagang pulsa dan paket data tidak signifikan atau sangat kecil sekali peningkatannya. Hal ini terlihat dari nilai koefisien regresi yang nilainya sangat kecil yaitu sebesar 0,002195. Peningkatan yang terjadi pada harga produk yang dijual sebesar satu juta rupiah hanya akan meningkatan pendapatan sebesar 2.195 rupiah.

Temuan yang sama juga terjadi pada jumlah saldo pulsa dimana variabel ini memiliki pengaruh yang positif namun tidak signifikan terhadap pedagang pulsa dan paket data. Sama seperti pada harga produk yang dijual, jumlah saldo pulsa memiliki pengaruh yang positif artinya apabila jumlah saldo pulsa mengalami peningkatan pada akan meningkatan pendapatan namun peningkatan pendapatnya tidak signifikan atau sangat sedikit peningkatannya. Peningkatan yang terjadi pada jumlah saldo pulsa sebesar satu juta rupiah hanya akan meningkatan pendapatan sebesar 57.948 rupiah.

Berbeda halnya dengan volume penjualan paket data dimana variabel ini memiliki pengaruh yang positif dan signifikan terhadap pendapatan pedagang pulsa dan paket data. Peningkatan volume penjualan paket data sebesar 1 unit akan meningkatan jumlah pendapatan pedagang pulsa dan paket data sebesar 42.748,54 rupiah. Variabel ini signifikan disebabkan karena kebanyakan konsumen adalah pengguna HP Android yang lebih mengutamakan paket data untuk koneksi internet ketimbang menggunakan pulsa.

Kendala yang paling sering dialami oleh para pedagang pulsa dan paket data adalah keterbatasan modal. Modal tentu saja menjadi faktor yang sangat penting untuk mengembangkan usaha. Oleh karena perlu adanya tindakan agar kendala modal yang dialami oleh para pedagang pulsa dan paket data dapat teratasi.

Salah satu program dari pemerintah yang bisa dicoba oleh para pedagang pulsa dan paket data adalah mengajukan pinjaman KUR (Kredit Usaha Rakyat) yang merupakan program dari pemerintah untuk membantu usaha UKM yang membutuhkan bantuan dana. Kredit Usaha Rakyat (KUR) merupakan program yang diinisiasi oleh pemerintah pusat namun yang mengakses dan menggunakan KUR adalah para pelaku usaha mikro kecil dan menengah. Pemerintah daerah Kabupaten Tanjung Jabung Barat berperan dalam mensukseskan program KUR kepada para pedagang pasar dengan cara melakukan sosialisasi, binaan dan bimbingan melalui Satuan Kerja Perangkat Daerah (SKPD).

\section{KESIMPULAN DAN SARAN}

\section{Kesimpulan}

Usia pedagang pulsa dan paket data terbanyak berada pada usia 24-26 tahun yaitu sebanyak 23 orang atau sekitar 31,08 \% dengan rata-rata umur adalah 25 tahun. Pedagang pulsa dan paket data didominasi oleh laki-laki yaitu sebanyak 58 orang atau sebesar 78,38\%. Tingkat pendidikan SMA merupakan tingkat pendidikan terbanyak 
diantara para pedagang pulsa dan paket data. Status perkawinan pedagang pulsa dan paket data terbanyak adalah status "Kawin". Pedagang pulsa dan paket data lebih banyak mengambil dari All Operator (Agen Langsung) yaitu sebanyak 58 orang atau $78,38 \%$. modal usaha dengan pedagang pulsa dan paket data terbanyak berada pada kisaran Rp. 2.657.143 - Rp. 3.514.285 yaitu sebanyak 24 orang atau 32,43\%. Harga dan paket data dengan responden terbanyak berada di kisaran Rp. 581.000 - Rp. 1.096 .428 yaitu sebanyak 38 orang atau $51,35 \%$. Jumlah saldo pulsa dengan pedagang pulsa dan paket data terbanyak adalah Rp. 242.857 - Rp. 314.285 yaitu sebanyak 24 orang atau $32,43 \%$. Volume penjualan paket data dengan responden terbanyak adalah 6-8 unit yaitu sebanyak 36 orang atau 48,65\%. Variabel modal (M), harga produk yang dijual (TH), jumlah saldo pulsa (JP) dan volume penjualan paket data (VP) berpengaruh signifikan secara bersama-sama (simultan) terhadap variabel pendapatan pedagang pulsa dan paket data di Kecamatan Tungkal Ilir Kabupaten Tanjung Jabung Barat (Y) sedangkan secara parsial variabel Modal Usaha (M) dan volume penjualan paket data (VP) memiliki pengaruh yang signifikan sedangkan harga produk yang dijual (TH) dan jumlah saldo pulsa (JP) tidak memiliki pengaruh yang signifikan terhadap variabel pendapatan pedagang pulsa dan paket data di Kecamatan Tungkal Ilir Kabupaten Tanjung Jabung Barat (Y).

\section{Saran}

Berdasarkan hasil analisis dapat diketahui bahwa faktor-faktor yang mempengaruhi pendapatan pedagang pulsa dan paket data adalah modal. Oleh karena itu, para pedagang lebih baik mencoba berbagai program peningkatan modal yang ditawarkan pemerintah terutama KUR untuk mengembangkan usaha dan menjaga keberlangsungan hidup usaha. Variabel lain yang berpengaruh signifikan adalah volume penjualan paket data. Oleh karena itu, para pedaganga haruslah selalu menjaga agar paket data selalu tersedia bagi konsumen terutama paket data yang murah dengan kuota yang melimpah.

\section{DAFTAR PUSTAKA}

Arikunto. (2006). Prosedur Penelitian Suatu Pendekatan Praktek. PT. Rineka Cipta. Jakarta

Firdaus, M. (2011). Ekonometrika Suatu Pendekatan Aplikatif. PT. Bumi Aksara. Jakarta

Hidayaji, S. (2010). Analisis Faktor-Faktor Yang Mempengaruhi Tingkat Pendapatan Usaha Counter Pulsa Di Kecamatan Gamping Sleman. Skripsi-FE. Universitas Muhammadiyah Yogyakarta. Yogyakarta.

Insukindro. (2003). Modul Ekonometrika Dasar. FE UGM. Yogyakarta.

Kuncoro. M. (2013). Mudah Memahami Dan Menganalisis Indikator Ekonomi. UPP STIM YKPN. Yogyakarta

Ma'rufaa, L.R. (2019). Pengaruh Modal Usaha, Tenaga Kerja, Jam Kerja Dan Lama Usaha Terhadap Pendapatan Usaha Counter Pulsa Di Kecamatan Gresik (Studi Pada Counter Pulsa Yang Terdaftar Di Pt. Multi Media Selular Cabang Gresik). Thesis-FE. Universitas Muhammadiyah Gresik. Gresik.

Masyhuri dan M. Zainuddin. (2008). Metodologi Penelitian Sosial dan Ekonomi,. Teori dan Aplikasi. Penerbit Alfabeta. Bandung

Perdana, P.S. (2009). Analisis Faktor - Faktor Yang Mempengaruhi Pendapatan Usaha Kios Pulsa Di Daerah Trosobo Kecamatan Taman Kabupaten Sidoarjo. SkripsiFE. UNP-Veteran. Jawa Timur.

Silalahi, U. (2010). Metode Penelitian Sosial. Bandung: PT. Refika Aditama

Sugiyono. (2011). Metode Penelitian Kuantitatif, Kualitatif dan R\&D. Penerbit Alfabeta. Bandung. 